\title{
Peran ibu dalam pendidikan karakter anak menurut Pandangan islam
}

\author{
Sri Mulyani \\ Dosen Institut Parahikma Indonesia \\ srymulyani@parahikma.ac.id
}

\begin{abstract}
This article elaborates the important roles of mothers in children's character education according to Islamic perspectives. Character education is absolutely important by all the glory of man lies in his character. The formulation of important issues to be discussed is the importance of family education, the maternal virtue in Islamic view and the mother's role in shaping the character of children.Family education is very important in Islam, since family is the main pillar for the formation of children's character. In family education, mothers hold a central role as primary and first educators. The posititon of the mother in Islamic view is glorius. As a proof of noble posititon of the mother in Islamic teaching, a mother is entitled to devotion of a child as much as three times more than the father. Mothers play crucial roles in shaping the chacarter of children. To perform such a noble task, mothers can do things like: providing prenatal education, giving good examples to children, instilling good characters from childhood such as honesty, discipline and responsibility; and building good communication between mother and child.
\end{abstract}

Key words: Character, Mother, Education, Islam

\section{Pendahuluan}

Membincang tentang karakter adalah hal yang sangat penting dan mendasar. Karakter adalah harta yang sangat berharga yang harus dimiliki setiap orang. Karakter adalah salah satu hal yangmembedakan manusia dengan makluk lainnya. Dalam Kamus Besar Bahasa Indonesia (KBBI) karakter diartikan sebagai sifat-sifat kejiwaan, akhlak atau budi pekerti yang membedakan seseorang dari yang lain; tabiat, watak. Menurut Budimansyah dikutip dari Sardjijo karakter adalah sifat pribadi yang relatif stabil dari individu yang menjadi dasar untuk perilaku standarnya sesuai dengan nilai-nilai sosial dan norma-norma ${ }^{88}$. Karakter yang baik akan

\footnotetext{
${ }^{88}$ Sardjijo. Character Education through Good Harmony Activities in School. The International Journal of Social Sciences and Humanities Invention 4(7): 3690-3694, 2017
} 


\section{An-Nisa', Volume XI Nomor 2 Desember 2018}

membimbing seseorang untuk bertindak sesuai dengan budi pekerti, norma dan nilai-nilai sosial yang baik.

Aristoteles tokoh filsafat barat mengatakan bahwa karakter yang baik adalah perilaku yang benar, yaitu perilaku yang benar dalam kaitannya dengan orang lain dan hubungannya dengan diri sendiri ${ }^{89}$. Lickona mengatakan bahwa karakter mempunyai tiga bagian yang saling terkait yaitu pengetahuan tentang moral, perasaan tentang moraldan perilaku moral - moral knowing, moral feeling, and moral behavior" ${ }^{\prime \prime 0}$. Lebih lanjut Lickona menjelaskan bahwa karakter yang baik adalah proses psikologis untuk mengetahui yang baik, menginginkan yang baik, dan melakukan kebiasaan baik dari pikiran, kebiasaan dari hati dan kebiasaan dari tindakan. Mengingat pentingnya karakter, institusi pendidikan mulai dari yang Pendidikan Anak Usia Dini (PAUD) sampai Perguruan Tinggi memegang peran penting dalam membangun nilainilai karakter yang baik di dalam maupun di luar kelas.

Pemerintah melalui Kementrian Pendidikan dan Kebudayaan telah mencanangkan pendidikan karakter sejak tahuan 2010. Pendidikan karakter ini dianjurkan pada tingkat pendidikan dasar sampai perguruan tinggi. Kebijakan tentang pendidikan karakter di institusi pendidikan ini bukan tanpa alasan. Pendidikan formal selama ini dinilai kurang mampu memberi output yang diharapkan. Dunia pendidikan memang mampu mengeluarkan siswa-siswa yang mempunyai intelektualitas yang tinggi namun dengan karakter yang memprihatinkan. Nurla Isna di kutip dari Munira (2014) mengatakan bahwa banyak dari lulusan sekolah yang memiliki nilai tinggi tetapi diperoleh dengan cara yang tidak murni seperti menyontek, plagiat, yang pada akhirnya mereka yang bernilai tinggi ini tidak memiliki perilaku cerdas, tidak memiliki integritas kepribadian yang baik, sebagaimana nilai akademik yang telah mereka raih di bangku sekolah ataupun kuliah ${ }^{91}$.

Penanaman dan penguatan pendidikan karakter sangat relevan untuk mengatasi berbagai masalah degradasi moral yang terjadi di Indonesia saat ini. Disadari atau tidak krisis moral telah melanda negeri ini dan melibatkan anak-anak. Krisis ini ditandai oleh berbagai bukti perilaku yang tak pantas seperti pergaulan bebas, penyalahgunaan narkoba, pencurian, pemerkosaan, pornograpi, pembegalan, penjambretan dan lain-lain. Perilaku siswa-siswi kita juga diwarnai dengan maraknya bullying dan tawuran di sekolah. Perilaku orang dewasapun tak jauh berbeda,

\footnotetext{
${ }^{89}$ Lickona, Thomas., Educating for Character: How Our Schools Can Teach Respect andResponsibility. (New York: Bantam Books, 1991) h. 50

${ }^{90}$ Ibid., h. 51

${ }^{91}$ Munirah, Peran Ibu dalam Membentuk Karakter Anak,Jurnal Aladuna vol 1 No 2 Desember2014 h. 254
} 
diwarnai dengan ketidakjujuran sehingga terjadi korupsi, kolusi, dan perselingkuhan. Lemahnya karakter bangsa terlihat pula pada disiplin dan tertib berlalu lintas, budaya antre, budaya baca sampai pada budaya bersih dan sehat, dan keinginan menghargai lingkungan masih jauh di bawah standar. ${ }^{92}$

Pendidikan karakter sangat dibutuhkan oleh setiap orang dari setiap kalangan, karena karakter yang akan menentukan baik buruknya perilaku seseorang. Karakter yang akan membimbing seseorang dalam bertindak dan menyikapi berbagai persoalan. Karakter yang baik akan membuat orang bertindak sesuai tata norma dan nilai dengan kejujuran, keteraturan, kedisiplinan, dan ketabahan dalam menghadapi berbagai persoalan hidup. Pendidikan karakter harus dilakukan disemua lini, melaui tiga pusat pendidikan yaitu lingkungan keluarga, lingkungan sekolah dan lingkungan masyarakat. Dari ketiga pusat pendidikan tersebut, pendidikan di lingkungan keluarga adalah yang pertama dan utama karena disinilah penanaman nilai-nilai karakter bisa dilakukan sejak awal kehidupan seorang anak. Dalam keluarga interaksi maksimal dilakukan antara orangtua dan anak. Karenanya,peran orangtua terutama ibu sangatlah vital dalam pendidikan karakter.

Berdasarkan uraian latar belakang diatas tulisan ini bertujuan untuk membahas tentang keutamaam ibu dalam Islam dan pentingnya peranan ibu dalam pendidikan karakter anak menurut pandangan Islam.

\section{Pentingnya Pendidikan Keluarga}

Keluarga adalah lingkungan yang pertama dan utama bagi anak. Keluarga adalah komunitas pertama dimana anak berinteraksi di awal kehidupannya. Di dalam keluargalah anak paling banyak menghabiskan waktu setiap harinya sehingga keluarga menjadi tempat pertama pembentukan karakter atau akhlaq anak sebelum dia berbaur dengan masyarakat luas. Dalam keluarga terjadi interaksi pendidikan pertama dan utama bagi anak yang akan menjadi pondasi dalam pendidikan selanjutnya ${ }^{93}$. Di keluarga anak tidak hanya berkomunikasi dan berinteraksi tetapi anak melihat contoh nyata tindakan dan perbuatan yang dilakukan seluruh anggota keluarganya terutama ayah dan ibunya. Perhatian, kasih sayang, dan bimbingan orangtua dalam keluarga akan menjadi pondasi perkembangan psikis dalam pembentukan karakter anak.

Sejalan dengan peran tersebut di atas, resolusi Majelis Umum PBB menjabarkan fungsi utama keluarga adalah sebagai wahana untuk mendidik, mengasuh dan mensosialisasikan anak,

\footnotetext{
${ }^{92} \mathrm{Ibid}$, h. 255

${ }^{93}$ Nur Uhbiyati. Ilmu Pendidikan Islam (Pustaka Setia, bandung: 1997), h. 237.
} 


\section{An-Nisa', Volume XI Nomor 2 Desember 2018}

mengembangkan seluruh anggotanya agar dapat menjalankan fungsinya di masyarakat dengan baik, serta memberikan kepuasan dan lingkungan yang sehat guna tercapainya keluarga sejahtera $^{94}$. Jadi keluarga mempunyai peranan penting dalam mempersiapkan anak sebelum mereka menjalankan fungsinya dengan baik dalam masyarakat. Salah satu peran keluarga adalah peran edukatif dimana keluarga menjadi tempat proses saling belajar diantara sesama anggota keluarga, dimana orangtua mendapat peran utama yang memberikan bimbingan, asuhan, contoh dan teladan ${ }^{95}$.

Pentingnya peranan pendidikan keluarga dalam membantu perkembangan peserta didik dapat dibuktikan dari hasil-hasil penelitian yang dikumpulkan oleh Daud (1994) yang menyatakan bahwa pendidikan keluarga memberi dukungan antara $24 \%$ sampai $67 \%$ tertadap prestasi belajar anak-anak ${ }^{96}$. Penelitian-penelitian tersebut membuktikan adanya keterkaitan yang kuat antara pendidikan keluarga terhadap prestasi belajar anak-anak disekolah. Anak yang mndapatkan bimbingan, asuhan, perhatian dan contoh yang baik dalam keluarga akan memperoleh prestasi yang lebih baik.

Islam sangat menekankan pentingnya pendidikan keluarga. Keluarga merupakan lembaga pendidikan yang pertama dan utama pada anak ${ }^{97}$. Dalam surah Al-Tahrim secara implisit ditegaskan peran orangtua untuk membawa seluruh keluarga dalam kebaikan yang menjauhkan mereka dari perilaku buruk yang akan membawa mereka ke neraka.

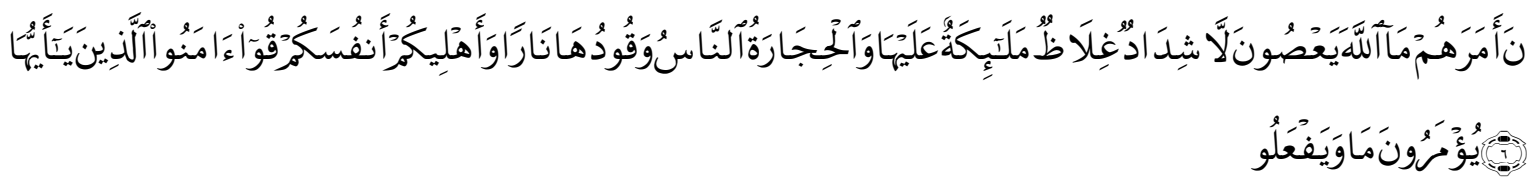

Artinyanya:

Hai orang-orang yang beriman, peliharalah dirimu dan keluargamu dari api neraka yang bahan bakarnya adalah manusia dan batu; penjaganya malaikat-malaikat yang kasar, keras, dan tidak mendurhakai Allah terhadap apa yang diperintahkan-Nya kepada mereka dan selalu mengerjakan apa yang diperintahkan.(QS.At-Tahrim:6)

Menurut Quraish Shihab dalam tafsir Al Misbah, ayat di atas memberikan tuntunan kepada kaum beriman yaitu dengan meneladani Nabi Muhammad SAW, tentang pendidikan

\footnotetext{
${ }^{94}$ Maria Ulfah Syarif. Rekonstruksi Peran dan Fungsi Keluarga dalam Pembentukan Karakter dan Intelektualitas Anak. Jurnal An-Nisa Volume IX No 2 Desember 2016, h. 142

${ }^{96}$ Husaini Daud, Lingkungan Keluarga Anak-anak Berprestasi Tinggi dan Anak-anak Berprestasi Rendah, Jurnal Pendidkan Jilid 1 no 2 Agustus 1994, h. 108-116

${ }^{97}$ Faud Ihsan, Dasar-dasar Pendidikan, (Cet. IV;Jakarta: PT Rineka Cipta,2005), h. 57
} 
yang harus bermula dari rumah, dan bertanggung jawab terhadap anak-anak, dan orang-orang disekitarnya dengan membimbing dan mendidik mereka agar terhindar dari api neraka ${ }^{98}$.

Secara eksplisit ayat tersebut menegaskan tugas orang tua dalam mendidik keluarga dengan mengarahkan,mendidik dan mengajarkan hal-hal yang membawa kepada kebaikan dan menghindarkan dari hal-hal yang membawa keburukan. Orang tua mempunyai tanggung jawab besar dalam menyelamatkan anak-anaknya dari keburukan dan kemungkaran. Anak yang mendapatkan pendidikan, asuhan dan perhatian yang baik akan tumbuh menjadi anak yang baik, begitu pula sebaliknya jika anak dididik dengan kekerasan, asuhan yang salah dan perhatian yang kurang maka iapun akan tumbuh menjadi anak yang berperangai tidak baik.

Para orang tua atau pendidik dan masyarakat akan dimintai pertanggung jawaban dihadapan Allah tentang pendidikan generasi ini apabila baik dalam mendidiknya maka generasi ini akan bahagia di dunia maupun di akhirat ${ }^{99}$.

Selanjutnya dalam surat An-nisa Ayat 9 Allah berfirman:

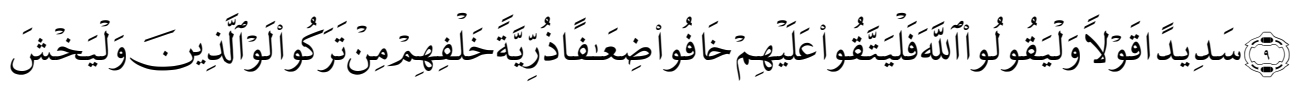

Dan hendaklah takut kepada Allah orang-orang yang meninggalkan anak-anaknya dalam keadaan lemah yang mereka khawatir terhadap (kesejahteraan mereka). Oleh sebab itu hendaklah mereka bertaqwa kepada Allah dan hendaklah mereka mengucapkan perkataan yang benar. (QS Annisa:9)

Menurut Imam Nawawi, makna dzurriyatan dhi'fan (keturunan yang lemah) dalam ayat tersebut adalah keturunan yang lemah dalam hal ekonomi yang menyebabkan kemiskinan, lemah dalam ilmu pengetahuan, lemah dalam hal pemahaman ilmu agama, dan lemah dalam akhlaqnya $^{100}$. Sehingga bisa disimpukan bahwa ayat tersebut Allah SWT memerintahkan orangtua untuk mempersiapkan keturunannya dengan baik secara fisik dan mental, dalam hal materi dan immateri

Islam juga menekankan pentingnya orang tua untuk memiliki anak yang soleh/solehah, yaitu anak yang mempunyai karakter / akhlaq yang baik yang taat kepada perintah Allah swt dan menjauhi larangannya. Karena anak yang soleh/solehah akan menyelamatkan orangtua baik di dunia maupun di akherat kelak. Dari Abu Hurairah diriwayatkan bahwa Rasulullah bersabda:

\footnotetext{
${ }^{98}$ M.Qurais Shihab, Tafsir Al Misbah, Vol 14, Lentera hati, (Jakarta : 2002), h. 326-327

${ }^{99}$ Syaikh Muhammad bin Jamil Zainu, Kiat Mencetak anak Shaleh, (Pustaka Ulil Albab, 2006) h. 4

${ }^{100}$ https://www.bacaanmadani.com/2018/04/kandungan-al-quran-surat-nisa-ayat-9.html
} 
Jika seorang anak Adam mati maka terputuslah seluruh amalnya kecuali tiga perkara, yaitu sedekah jariah, ilmu yang bermanfaat dan anak yang soleh yang akan mendoakannya kedua orangtuanya(HR Muslim).

Dalam hadis tersebut disebutkan bahwa anak yang saleh akan menjadi amalan yang tidak pernah putus meskipun orang tua telah meninggal dunia. Hal ini mengindikasikan betapa pentingnya akhlak atau karakter seorang anak yang berpengaruh bagi kehidupan orang tua bahkan dikehidupan setelah kehidupan dunia. Peran utama orangtualah dalam membentuk karakter anak melalui pendidikan dalam keluarga, mulai dari dalam kandungan sampai ia tumbuh dewasa.

Imam al Gazali mengatakan bahwa anak adalah amanah bagi orang tuanya. Hati anak yang suci ibarat emas permata yang murni yang siap ditempa dan dibentuk sesuai keinginan pembentuknya. Ia cenderung menerima pahatan atau perlakuan apa saja padanya. Jika ia dibiasakan dengan kebaikan maka ia akan tumbuh menjadi orang yang baik. Tetapi jika ia di biasakan melakukan keburukan dan ditelantarkan dalam pengajaran maka ia akan tumbuh menjadi orang yang celaka dan binasa ${ }^{101}$. Seperti dalam sebuah hadis yang diriwayatkan oleh Bukhari yang artinya:

Setiap anak itu dilahirkan dalam keadaan fitrah, maka hanya kedua orang tuanyalah yangakan menjadikannya seorang yahudi atau seorang nasrani atau seorang majusi. (HR.Bukhari)

\section{Keutamaan Ibu dalam Pandangan Islam}

Allah menempatkan Ibu pada posisi yang sangat mulia. Ibu adalah orang yang pertama dan utama yang berhak menerima bakti anak. Ibu adalah seorang perempuan yang diberi amanah oleh Allah SWT untuk mengandung,melahirkan, dan menyusui serta mendapat tanggung jawab untuk merawat, membesarkan dan mendidik anak. Ibu mendapat keutamaan yang lebih besar dibandingkan ayah, hal ini disebutkan dalam sebuah hadis yang artnya:

Dari Abu Hurairah, ia berkata: Seseorang datang kepada rasulullah saw. dan berkata, wahai rasulullah! kepada siapakah aku harus berbakti pertama kali? Nabi menjawab, ibumu! Orang tersebut bertanya kembali, kemudian siapa lagi? Beliau menjawab, ibumu! Orang tersebut bertanya kembali kemudian siapa lagi? Nabi menjawab, kemudian kepada ayahmu.(HR. Bukhari dan Muslim).

Dalam hadis tersebut Rasulullah Saw mengindikasikan keutaman berbakti kepada ibu, dengan menyebut nama ibu tiga kali baru kemudian menyebutkan kata ayah. Imam al-Qurthubi

\footnotetext{
${ }^{101}$ Syaik Jamal Abdul Rahman, Islamic Parenting: Mendidik Anak Metode Nabi, (Solo: Aqwam, 2014), h.12
} 
menjelaskan bahwa hadis tersebut menunjukkan kecintaan dan kasih sayang terhadap seorang ibu harus tiga kali lipat besarnya dibandingkan terhadap seorang ayah ${ }^{102}$.

Dalam bukunya Lentera Hati, Quraish Shihab mengatakan ada dua istilah dalam bahasa arab yang berarti ibu yaitu al-umm dan al-walidah. Al-umm berarti ibu kandung dan bukan ibu kandung, sedangkan al walidah berarti ibu kandung. Menurutnya, Kata al umm yang berarti ibu berasal dari kata yang sama yang membentuk kata imam (pemimpin) dan umat yang kesemuanya bermakna yang dituju atau yang diteladani. Jika ibu berfungsi sebagai umm, maka ia akan menciptakan pemimpin-pemimpin melalui ajaran dan tauladannya. Sebaliknya jika seorang ibu tidak berfungsi sebagai umm, maka tidak akan lahir pemimpin-pemimpin yang patut di teladani sehingga umat akan hancur ${ }^{103}$.

Dalam surah Al-ahqaaf ayat 15 Allah berfirman:

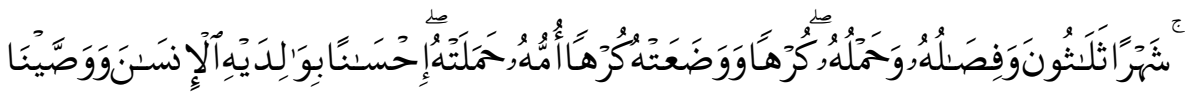

Artinya:

Kami perintahkan kepada manusia supaya berbuat baik kepada dua orang ibu bapaknya, ibunya mengandungnya dengan susah payah, dan melahirkannya dengan susah payah (pula). Mengandungnya sampai menyapihnya adalah tiga puluh bulan(QS. AlAhqaaf/46:15).

Dalam surat ini Allah memerintahkan manusia untuk berbuat baik kepada orangtuanya, dan berbakti kepada-Nya. Dalam surat ini juga Allah juga menyebutan perjuangan seorang ibu secara khusus, ibu yang mengandung dan melahirkannya dengan susah payah dan menyusinya sampai tiga puluh bulan. Dengan penyebutan perjuangan ibu tesebut menekankan pentingnya seoang anak berbakti dan memuliakan ibunya.

Dalam surat Al-Isra ayat 23 Allah juga memerintahkan manusia agar berbuat baik kepada ayah ibunya dengan sebaik-baiknya. Allah memerintahkan untuk berkata sebaik-baiknya kepada orangtua dan melarang seorang anak menolak perintah atau perkataan orangtuanya dengan mengatakan "ah".

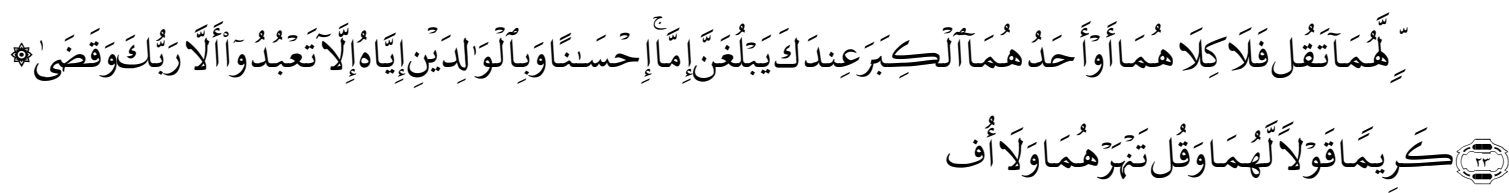

Artinya:

\footnotetext{
${ }^{102}$ Op. Cit, h. 257

${ }^{103}$ Quraish Shihab,Tafsir Al Misbah, Lentera Hati,(Bandung: Mizan, 2000), h. 258
} 


\section{An-Nisa', Volume XI Nomor 2 Desember 2018}

Dan, Tuhanmu telah memerintahkan supaya kamu jangan menyembah selain Dia dan hendaklah kamu berbuat baik pada ibu bapakmu dengan sebaik-baiknya. Jika salah seorang diantara keduanya atau kedua-duanya sampai berumur lanjut dalam pemeliharaanmu, maka sekali-kali janganlah kamu mengatakan kepada keduanya perkataan "ah" dan janganlah kamu membentak mereka dan ucapkan kepada mereka perkataan yang mulia.(QS. Al-Isra"/17:23).

\section{Peran Ibu dalam Membentuk Karakter Anak}

Seorang ibu mempunyai peran sentral daam membentuk karakter anak. Ibu sebagai sosok yang paling dekat dan memiliki ikatan yang paling kuat dengan anak semenjak anak dalam kandungan. Ikatan psikologis antara ibu dan anak ini disebut Maternal bonding. Maternal bondng merupakan dasar penting dalam pembentukan karakter anak karena aspek ini berperan dalam pembentukan dasar kepercayaan kepada orang lain (trust) pada anak ${ }^{104}$.

Selain hubungan kedekatan psikologis, pola asuh orangtua terutama ibu sangat berpengaruh terhadap pembentukankarakter anak. Pola asuh ibu dibedakan menjadi tiga macam, yaitu pola asuh otoriter, pola asuh demokratis; dan pola asuh permisif. Pola asuh otoriter mempunyai ciri orangtua tua atau ibu yang membuat semua keputusan dan mengharuskan anak untuk tunduk, patuh tanpa bertanya pada keputusannya. Pola asuh demokratis memunyai cirikhas pola asuh yang memberikan kesempatan anak untuk berdiskusi membicarakan apa yang anak inginkan. Sedangkan pola asuh permisif mempunyai karakteristik memberikankebebasan yang luas dengan minim pengawasan dan kontrol dari orangtua ${ }^{105}$.

Keberadaan seorang ibu yang menjadi sosok paling dekat dengan anak, menjadi orang kepercayaan pertama bagi anak merupakan posisi yang strategis untuk membentuk atau membimbing anak. Memberikan teladan, menanamkan nilai-nilai sejak dini, membanguan komunikasi yang baik adalah cara-cara menanamkan karakter pada anak.Secara rinci,beberapa hal yang bisa dilakukan seorang ibu dalam membentuk karakter anak yang baik adalah sebagai berikut:

\section{Prenatal Education}

Pendidikan anak sudah dimulai semenjak anak masih dalam kandungan. Prenatal education ini biasa di sebut indirect education yang bisa dilakukan oleh ibu yang mengandungnya. Peneitian mengatakan bahwa bayi yang dalam kandungan dapat mendengarkan, merasakan dan menerima stimulasi yang diberikan dari luar.

\footnotetext{
${ }^{104}$ Rianawati,Peran Ibu dalam Pendidikan Karakter Anak Usia Dini Menurut Pandangan Islam, Research Gate, www.Researchgate.net/publication/319908079

${ }^{105}$ Elizabeth B. Hurlock,Perkembangan Anak, (Ed. VI; Jakarta: Erlangga, 2000), h. 205.
} 
Berbagai penelitian telah membutikan pendidikan prenatal mempunyai dampak positif untuk perkembangan intelejensi dan karakter anak. Sebuah penelitian yang dilakukan di Bangkok yang dipimpin oleh C. Phantura Amphon menemukan bahwa bayi yang diberikan stimulasi pralahir cepat mahir bicara, menemukan suara, menyebutkan kata pertama, tersenyum dengan spontan, lebih tanggap dan juga mengembangkan pola sosial yang lebih baik saat ia dewasa ${ }^{106}$.

Menurut Ibnu qoyyim al-jauziah konsep pendidikan prenatal meliputi: (1) fungsi pendengaran, penglihatan dan hati sejak bayi dalam kandungan, (2) sikap orangtua jauh sebelumnya yaitu pada saat memilih pasangan, menikah, melakukan hubungan suami istri, memohon anak,, mengandung dan melahirkan, (3) perkembangan janin dari proses pembuahan (nutfah), mulai berbentuk segumpal darah ('alaqah), dan segumpal daging (mudlgah). Aspekaspek yang mempengaruhi pendidikan prenatal menurut Ibnu Qoyyim adalah aspek makanan dan lingkungan ${ }^{107}$. Ibu hamil harus makan makanan halal dan mengandung nutrisi dan menciptakan lingkungan yang kondusif.

Beberapa metode untuk mendidik anak dalam kandungan menurut Isna $\mathrm{N}^{108}$ yang pertama adalah metode doa, menjadikan doa sebagai senjata utama dalam masa prenatal dengan banyak memanjatkan doa agar dikaruniai anak yang saleh, yang mempunyai karakter tangguh. Para nabi dan orang saleh terdahulu banyak menggunakan metode doa. Kedua, metode ibadah baik ibadah wajib maupun ibadah nunah. Metode membiasakan anak dengan ibadah akan menguatkan spiritual, mental dan keimanan mereka ketika mereka lahir.

Ketiga, metode membaca dan menghafal. Metode ini berguna untuk menstimulasi otak anak. Menurut penelitian saat usia anak dalam kandunganmencapai 20 minggu (5 bulan) anak sudah bisa menyerap informasi dan stimulasi yang diberikan oleh ibunya. Metode keempat adalah metode dzikir, dzikir akan menumbuhkan kesadaran untuk selalu mengingat Allah dan menyandarkan hidup kepada Allah semata. Metode kelima adalah dialog, metode ini digunakan sebagi metode interaktif antara bayi dalam kandungan dan anggota keluarga seperti ayah, ibu, dan kakak. Metode ini melatih bayi berinteraksi dan berkomunikasi dengan mereka yang berada diluar Rahim.

\footnotetext{
${ }^{106}$ Carr, rene, Van De \& Lehrer. March 1999, Cara Baru Mendidik Anak Sejak Dalam Kandungan (Bandung: Khaifa), h. 32

${ }^{107}$ Ulil Absor,Konsep Pendidikan Prenatal Presepsi Inno Qoyyim Jauziah, Sripsi, Jurusan Pendidikan Agama Islam Fakultas Tarbiyah UIN Maliki Malang 2019

${ }^{108}$ Isna N,Mencetak Karakter Anak Sejak Janin, ( Jogja: Diva Press, 2012), h. 34
} 


\section{An-Nisa', Volume XI Nomor 2 Desember 2018}

\section{Memberikan Teladan yang Baik}

Keteladanan adalah unsur penting dalam mendidik. Banyak ahli yang mengatakan metode mendidik dengan keteladanan paling efektif. Ini disebabkan sifat alami anak yang akan lebih cepat menangkap hal-hal yang konkrit dibandingkan hal yang abstrak. Memberikan teladan berarti memberikan contoh berupa tidakan, perkataan, ataupun sikap kepada anak.

Seorang ibu adalah mendidik pertama yang di jadikan role model atau contoh bagi anakanaknya. Cara ibu berbicara, bersikap/berprilaku, beramal, beribadah dan bersosialisasi akan dicontoh oleh anak. Karenanya seorang ibu harus memberikan contoh-contoh yang baik mulai dari perkataan sampai pada perbuatannya. Seorang ibu yang suka berbicara tidak sopan, mengumpat mencaci akan mencetak anak-anak pencaci. Begitupun ibu yang berperilaku kasar kepada anak seperti sering memukul, mencubit akan menjadikan anak yang berkarakter kasar nantinya.

Selain menjadikan dirinya teladan, ibu juga harus bekerja sama bersama ayah dan anggota keuarga yang lain untuk sama-sama memberikan teladan yang baik. Karena anak adalah peniru ulung yang sangat mudah mengikuti apapun yang dilihat disekitarnya. Selain itu, ibu bisa membiasakan menceritakan kisah-kisah keteladanan Rasulullah SAW dan para sahabat. Kisahkisah keteladanan ini bisa dijadikan cerita sebelum tidur. Cerita yang dibacakan sebelum tidur akan diserap dalam alam bawah sadar anak, sehingga menjadi salah satu input atau acuan dalam berperilaku.

\section{Menanamkan Karakter yang Baik}

Menanamkan karakter yang baik harus dimulai sedini mungkin. Karakter jujur, disiplin, dan bertanggung jawab adalah diantara karakterprioritas yang harus diajarkan semenjak kecil. Kejujuran adalah karakter yang paling urgen untuk ditanamkan. Fadillah (2012) dalam Daviq Chairilsyah mengatakan bahwa jujur merupakan perilaku yang patuh dalam perkataan, tindakan, dan pekerjaan.Artinya orang yang jujur, perkataannya sesuai dengan perbuatan/tindakan. Sedangkan menurut Robert T. Kiyosaki jujur diibaratkan seperti aset. Artinya, jujur adalah sesuatu yang sangat berharga ${ }^{109}$.

Menanamkan karakter jujur harus dimulai dengan pembiasaan setiap hari. Hal yang pertama adalah memberikan contoh kepada anak untuk selalu sesuai antara perkataan dan perbuatan. Seringkali terjadi seorang ibu berbohong kepada anak hanya agar anak tidak

\footnotetext{
${ }^{109}$ Daviq Chairilsyah,Metode dan Tehnik Mengajarkar Kejujuran pada Anak Sejak Usia DIni,Jurnal Educhild Vol.5 No 1 Tahun 2016. h. 9
} 
menangis, seperti pergi secara diam-diam, atau mengatakan pada anak bahwa ia akan pergi sebentar padahal kenyataannya ibu pergi untuk kerja seharian. Pembiasaan jujur ini juga bisa dilakukan dengan memahamkan anak akan hak milik. Misalnya ketika anak pulang membawa mainan teman, ibu harus memberi tahu bahwa mainan itu bukan miliknya dan mewajibkan anak untuk mengembalikannya.

Hal lain yang perlu dibiasakan adalah mengajarkan anak untuk tidak menyontek di sekolah. Selain memberikan pemahaman bahwa menyontek itu perbuatan yang tidak baik, ibupun harus mempunyai paradigma yang berorientasi pada proses bukan hasil. Hal yang tak kalah penting agar anak mempunyai karakter jujur adalah,ibu tidak marah ketika anak mengakui telah melakukan kesalahan.

Begitu juga dengan karakter kedisiplinan anak, ibu bisa membiasakan dengan hal-hal yang sederhana seperti membuat kesepakatan dengan anak. Kesepakatan ini harus dipatuhi dan jika dilanggar akan mendapat hukuman disiplin. Misalnya kesepakatan untuk tidak tidur larut malam dan kesepakatan untuk bangun pagi. Kesepakatan waktu menonton TV atau bermain gadget dan lain sebagainya.

Karakter bertanggungjawab (integritas) bisa ditanamkan dengan memberikan tugas kepada anak. Misalnya tugas merapikan mainan, membersikan tempat tidur, atau membantu ibu membersihkan rumah. Tugas atau tanggung jawab yang diberikan anak tentunya harus disesuaikan dengan usia. Misalnya, pada usia 3 tahun anak bisa dibiasakan untuk merapikan mainannya sendiri, saat usia lima tahun anak sudah bisa dibiasakan merapikan tempat tidur dan mencuci piringnya sendiri setelah makan. Pada usia 7 tahuan, anak sudah bisa diberikan tugas membantu ibu atau ayah seperti menyapu, menyiram tanaman, atau mencuci sepatu sekolahnya sendiri.

Kebiasaan-kebiasaan yang ditanamkan sejak kecil akan berkembang menjadi karakter ketika mereka dewasa sehingga mereka akan melakukan hal-hal yang sudah diajarkan tersebut secara otomatis, dengan kesadaran sendiri tanpa perintah atau paksaan dari orang lain.

\section{Melatih Kemandirian}

Kemandirian adalah karakter penting yang harus ditanamkan pada anak sejak dini. Karakter mandiri yang akan membimbing anak kelak untuk tidak menyusahkan dan bergantung pada orang lain. Kemandirian juga akan membawa anak menjadi pribadi yang kuat dan tabah dalam menghadapi berbagai kesulitan dan cobaan hidup. Dengan kemandirian, manusia merasa 


\section{An-Nisa', Volume XI Nomor 2 Desember 2018}

bahwa dirinya bertanggung jawab terhadap dirinya dan memahami bahwa untuk mendapat sesuatu dibutuhkan proses ${ }^{110}$.

Melatih kemandirian bisa dimulai dari hal yang sederhana seperti mengajarkan anak untuk makan sendiri sejak balita. Hal ini tampak sederhana tetapi dampaknya sangat besar bagi perkembangan anak. Ada beberapa cara yang bisa digunakan untuk mengajarkan anak makan sendiri. Misalnya dengan menyediakan kursi khusus agar anak bisa makan bersama anggota keluarga dimeja makan sehingga anak melihat dan meniru cara orang dewasa makan. Ajarkan anak untuk makan di rumah bukan dihalaman atau dijalan, sediakan waktu khusus untuk mengajari anak makan di dalam rumah. Cara lainnya adalah dengan menciptakan suasana menyenangkan saat makan, ibu bisa mendesain menu makanan dalam bentuk yang unik sehingga anak tertarik untuk mengambilnya. Tidak lupa ibupun harus mengapresiasi dengan memberikan anak pujian saat anak bisa makan sendiri.

Mengajarkan kemandirian harus beretahap sesuai dengan tingkatan usia. Saat anak usia 5 tahun anak sudah bisa diajarkan untuk melakukan aktifitas mandi cuci kakus (MCK) sendiri. Meskipun diusia ini masih harus diikuti pengawasan orangtua. Ketika anak usia 6 tahun, ia sudah bisa diajarkan untuk tidur sendiri. Begitupun ketika anak sudah memasuki bangku sekolah, ibu perlu mengajarkan anak untuk mengerjakan tugas sekolah secara mandiri, meskipun bantuan tetap diberikan oleh ibu seperti memberikan penjelasan atau contoh ketika anak tidak memahami tugasnya.

\section{Membangun Komunikasi yang Baik}

Komunikasi mempunyai peran penting dalam membina hubungan, termasuk hubungan antara orangtua dan anak. Seorang ibu harus membangun komunikasi yang baik dengan anak agar anak tumbuh dengan kondisi mental dan psikologis yang baik. Komunikasi yang baik juga akan menumbuhkan rasa hormat anak kepada ibu. Selain itu komunikasi yang baik dapat menarik anak untuk bersikap terbuka dengan ibunya. Keterbukaan ini penting saat anak menginjakusia remaja atau dewasa, masa dimana anak akanmenemukan berbagai tantangan dan problematika hidup. Dengan terbangunnya komunikasi yang baik sejak kecil anak akan terbiasa terbuka menceritakan apa saja masalah yang ia hadapi diluar rumah, sehingga anak bisa mendapatkan solusi dan tidak mencari pelarian pada hal-hal yang tidak baik.

${ }^{110}$ Munira, Op. Cit. h. 262 
Komunikasi yang baik dapat dibangun dengan cara-cara sebagai berikut. Pertama, biasakan untuk mengadakan kontak mata saat berkomunikasi dengan anak. Kontak mata antara ibu dan anak ini penting untuk menjalin kedekatan emosional saat berkomunikasi.

Kedua, memilih posisi yang sejajar dengan anak. Ketika berbicara dengan anak usahakan untuk posisi yang setara dengan anak misalnya dengan cara duduk atau berjongkok, hal ini akan memberikan kesan penghargaan kepada anak.

Ketiga, adakan kontak fisik dengan anak saat berkomunikasi seperti sentuhan, elusan atau dekapan yang membuat anak nyaman dekat dengan ibunya. Sehingga anak akan betah berlamalama berbicara atau berkomunkasi dengan ibunya.

Keempat, menggunakan kata-kata yang baik dan sopan saat berbicara dengan anak. Apapun yang ibu katakan itulah yang akan anak tiru, bagaimana sikap ibu saat berbicara itulah yang akan anak lakukan ketika ia berbicara dengan ibunya ataupun orang lain.

Kelima, hindari kata-kata menghakimi atau memojokkan anak. Ketika anak melakukan kesalahan, ibu harus menanyakan dengan cara yang baik dan sabar tentang kesalahan anak. Ibu boleh menasehati dengan kata-kata yang memotivasi anak bukan menghakimi.

Keenam, hindari melabeli anak. Banyak ibu-ibu yang tanpa sadar sering melabeli anaknya dengan hal-hal yang buruk seperti bodoh, tolol, malas, nakal. Ucapan ibu adalah doa, sehingga semaksimal mungkin ibu harus berusaha untuk memberikan sebutan yang baik kepada anak, seperti pintar, saleh/salehah, rajin. Secara psikologis kata-kata tersebut akanmenjadi sugesti di alam bawah sadar anak.

\section{Kesimpulan}

Dari uraian diatas dapat disimpulan beberapa hal, sebagai berikut:

1. Pendidikan keluarga sangat penting bagi anak. Karena keluarga adalah institusi pertama yang anak kenal, dan keluarga adalah tempat untuk menempa atau membentuk karakter anak. Pentingnya pendidikan keluarga disebutkan berkali-kali dalam al-Quran seperti dalam suratAt-Tahrim ayat 6 dan surat annisa ayat 9. Selain itu pentingnya pendidikan dalam keuarga juga di sebutkan dalam beberapa hadis.

2. Kedudukan ibu sangat mulia dalam Islam. Sebagai bukti kemuliaan ibu, ibu berhak mendapatan bakti dari anak tiga kali lipat dibanding anak. Keistimewaan kedudukan ibu juga disebutkan dalam al-Quran dan hadist.

3. Seorang ibu mempunyaiperan yang sangat penting dalam pendidikan karakter anak. Beberapa hal yang bisa dilakukan ibu untuk menenuaikan tugas mulia tersebut adalah: 


\section{An-Nisa', Volume XI Nomor 2 Desember 2018}

a. Memberikan pendidikan prenatal atau pendidikan semasa anak dalam kandungan

b. Memberikan contoh atau teladan yang baik

c. Menanamkan karakter jujur, disiplin dan tanggung jawab sejak dini

d. Menanamkan kemandirian

e. Membangun komunikasi yang baik dengan anak

\section{Daftar Pustaka}

Carr, rene, Van De \& Lehrer. March 1999, Cara Baru Mendidik Anak Sejak Dalam Kandungan (Bandung: Khaifa)

Absor, Ulil. Konsep Pendidikan Prenatal Presepsi Inno Qoyyim Jauziah, Sripsi, Jurusan Pendidikan Agama Islam Fakultas Tarbiyah UIN Maliki Malang 2019

Chairilsyah,Daviq. Metode dan Tehnik Mengajarkar Kejujuran pada Anak Sejak Usia Dini, Jurnal Educhild Vol.5 No 1 Tahun 2016. h. 9

Daud, Husaini. Lingkungan Keluarga Anak-anak Berprestasi Tinggi dan Anak-anak Berprestasi Rendah di SMA Negeri Kabupaten Pidie Sigli, Jurnal Pendidkan Jilid 1 no 2 Agustus 1994, h. 108-116

Departemen Agama,Al-Qur'an dan Terjemahannya. Jakarta: Surya Cipta Aksara, 1997.

Hurlock, Elizabeth B. Perkembangan Anak, Ed. VI; Jakarta: Erlangga, 2000.

Ihsan, Faud. Dasar-dasar Pendidikan, Cet. IV;Jakarta: PT Rineka Cipta,2005.

Isna, N. 2012. Mencetak Karakter Anak Sejak Janin. Diva Press. Jogja

Lickona, Thomas., Educating for Character: How Our Schools Can Teach Respect and Responsibility. New York: Bantam Books, 1991.

Munirah, Peran Ibu Dalam Membentuk Karakter Anak Perspektif Islam. Jurnal Auladuna, Vol. 1 No. 2642 Desember 2014: 253-264.

Nata, Abudin.Kapita Selekta Pendidikan Islam. Bandung: Angkasa, 2003.

Nur Uhbiyati, Ilmu Pendidikan Islam. Bandung Pustaka Setia, 1997. 
Rahman, Syaik Jamal.Islamic Parenting: Mendidik Anak Metode Nabi. Solo: Aqwam, 2014.

Rianawati, Peran Ibu dalam Pendidikan Karakter Anak Usia Dini Menurut Pandangan Islam, Research Gate, www.Researchgate.net/publication/319908079

Sardjijo.Character Education through Good Harmony Activities in School. The International Journal of Social Sciences and Humanities Invention 4(7): 3690-3694, 2017.

Shihab,Quraish.Tafsir Al-Misbah: Pesan, Kesan, dan Keserasian Al-Q ur'an. Jakarta: Lentera Hati, Cet. IX, 2008.

Syarif,Maria Ulfah.Rekonstruksi Peran dan Fungsi Keluarga Dalam Pembentukan Karakter Dan Intelektualitas Anak(Telaah makna lafaz "IQRA" dalam Surah Al-Alaq Ayat 1-5). JurnalAn-Nisa', Volume IX Nomor 2 D esember 2016.

Zainu, Syaikh Muhammad bin Jamil.Kiat Mencetak anak Shaleh. Pustaka Ulil Albab, 2006.

https://www.bacaanmadani.com/2018/04/kandungan-al-quran-surat-nisa-ayat-9.html 